\title{
On Teaching Political Education Subjects in Secondary Education
}

\author{
Georgios D. Bikos* \\ Teacher at the Hellenic Open University, the University of Athens, the School of Pedagogical and Technological \\ Education and tutor on contract at the Emeritus Professor level at the University of Western Attica, Greece \\ *Corresponding Authors: Georgios D. Bikos, Teacher at the Hellenic Open University, the University of \\ Athens, the School of Pedagogical and Technological Education and tutor on contract at the Emeritus \\ Professor level at the University of Western Attica, Greece
}

\begin{abstract}
After we analyse the terms political thinking and critical political thinking, as two of the main kinds of thinking that sociopolitical education subjects should cultivate among students of secondary education, we propose different teaching approaches which may promote these forms of thinking, so that students can become capable of analysing critically and perceiving politically the current and existing sociopolitical reality. Finally, we suggest teaching methods and techniques that will help students adopt attitudes that will make students acquire attitudes that embrace political participation in an effort to increase the probability that they will become active citizens, as adults, following a democratic path.
\end{abstract}

Keywords: Active Citizen, Critical Thinking, Critical Political Thinking, Curricula, Teaching Methodology

\section{Preface}

All those engaged in education, either as teachers or scientists specialised in Education Sciences or researchers, have long concluded in the important role of not only what we teach, in other words what we each time choose to teach students, but also how, i.e. the method we employ to teach that something to students, in general. In fact, the Teaching science itself does nothing else but discuss the method of (every) particular teaching -i.e. what we call Principles and Methods of the teaching act (: teaching methodology)-, but also, to a certain extent, define purposes and set objectives that teaching should involve. Thus teaching methodology is substantially, systematically, orderly and thoroughly engaged in the how aspect. Therefore, it is every time useful to study Teaching Methodology or examine issues under the spectrum of Teaching Methodology. However, while the science of General Teaching has been developed for centuries now, the Teaching of particular subject areas taught in primary and secondary education has only marginally been elaborated on. The article that follows attempts to make a contribution in the subject area of Special Teaching related to the field of Political Science taught in secondary schools, making a relevant proposition for (academic) discussion in an effort to inspire and also steer, if not guide, those teachers who wish to instruct based on it or apply/implement its constituents.

\section{INTRODUCTION}

In order to clarify the purpose that teaching methodology should serve, particularly the methodology we consider appropriate to be used in sociopolitical education subjects in secondary education, we deem it necessary to refer, from the very beginning, to the relationship that we believe should exist between the political education provided by schools and the existing sociopolitical reality. Here we adopt a principle which is neither absolutely neutrality nor, let alone, value neutrality, as Weber (1991) would prefer, not even a principle that defends a militant education or a militant school, like a pure Marxist pedagogist or Marxist analyst of education -and committed to traditional Marxismwould suggest. In that respect, we should stress that, especially in secondary education, the syllabus should have an intrinsic connection with the sociopolitical reality, exactly as this is - that is, it should relate to the actual reality, not an ideal one, model/idyllic and idealised or idealist. (About the concept of the ideal type that Weber introduced, see Weber, 1978: 19-20.) 
Of course, the idea that the school should be connected to society has already been stressed by Dewey and Claparède (Danassis-Afendakis, 1993: 103-106, 126) many years ago. Today, it goes without saying that the school has a close and intrinsic connection to society, but there is a specific theoretical perception -which, in fact, today is (to a great extent) dominant- which wants the school to be 'open' to the society (Damanaki, Koulaidis, Kokkos, Lamnias, \& Dimopoulos, 2006). Thus, school and society build a form of relationship and interact. However, what we feel we should stress at this point is that, as is commonly known, the existing social reality has so many and such kind of (serious) issues that it should change. And this transformation of our social world should not only be initiated, but also caused by acts, initiatives and interventions on the part of its own residents; i.e. the people. In order for a person to decide to develop acts towards reforming the world, they should have first assessed the reality they live negatively and thought that it is not easily bearable as it is. And, at this very point, the issue of critical thinking is posed (Korres, 2007: 32-34); because in order for someone to be in a position to make any assessment, they should have developed critical thinking.

Hence, we will shortly discuss what the secondary school needs to do in order to promote that kind of critical thinking amongst students which will make them -on condition, of course, that certain other prerequisites apply as well-improve today's world through their daily social action and way of living. (How important it is to cultivate critical thinking among students in order for them to be socially integrated as democratic citizens is stressed in Battistoni's work (Karakatsani, 2008: 154.)

\section{Content and Methods to Cultivate Critical Political Thinking and Ways to Educate ACTIVE Citizens}

Starting with certain necessary conceptual definitions, we should note that when using the term critical thinking we mean the way of thinking that allows: First, the assessment of a position, reasoning and reality. Second, the comparison of certain positions, sets of reasoning and realities that do not seem equivalent, but also differences among positions, sets of reasoning and realities seemingly the same. And the third and last feature of critical thinking is that it allows us to predict the development of facts in reality, thus enabling whoever thinks critically to be also far-sighted. (Generally about critical thinking, see, indicatively, in Kyriakidis, 2006.)

Having analysed the term critical thinking, we turn, at this point, to social thinking. With this term we mean the way of thinking that allows us to understand how society works in its entirety and also the basic and less invisible relationships among the various social phenomena and social institutions. Thus, using the conceptually narrower term critical social thinking we mean the way of thinking that allows us, after we first realise which elements of social life constitute social issues, first, to identify the connection-dependence relationships that exist among them and also among them and some other (social, economic and political) facts which are not considered to be "issues" and, second, examine the main causes of each of the most common social issues and social phenomena.

Moreover, as critical social thinking borrows many of its features from the general critical thinking, it allows -and that is its main characteristic- one more thing: the assessment of every social situation, and also, often, the prediction of the development of an existing social reality. But every assessment of a fact is gleaned only in relation to another one, real or ideal element that works -consciously or unconsciously- as a role model for this assessment. Therefore, it is useful, here, to refer to some specific features that the syllabus of the secondary school should have so that it can, along with other factors, shape tomorrow's citizens who will be able to change the world. Hence, it is of utmost importance for students to be taught alternative models -which respond to a "vision" about realityrelating to the establishment of the world, everyday life, living together and human communication or human relationships, as these are interweaving, developing and evolving in the public sphere; because this way, not only will they ascertain that our world is not the only one that human intellect can perceive or the only possible to exist, but they will also have certain stimuli to start thinking in a similar manner, shaping their own image of a desired world or adopting one from those already offered. In fact, the presentation of these alternative models can even be made as part of the presentation of the most well-known sociopolitical systems that the various ideologies and currents of political thinking propose; it may also be achieved through literature, theatre and cinematography, which are all taught as part of the subjects related to Art. Moreover, the Political Education teacher in Junior and Senior High School -and possibly primary school- may even use some pieces of art as teaching tools. 
Another way through which schools can make students want to change the world is teach them analytically about the deficiencies and controversies of today's social, economic and political reality, and later elaborate on the general direction their "solutions" should or may take and, finally, invite them to find alternative solutions to (re)structure the existing reality and discuss them in class. (Some of the students may even express an interest to act in a way that would put these suggestions into practice, exactly because they will be their own suggestions.) On the other hand, some pedagogists may be -to a certain extent- justifiably worried that if students are taught about all the malfunctions and controversies of the social structure, they will end up being so pessimistic that they will, most probably, not only be unwilling to change the social stage, but even develop nihilistic and selfdestructive tendencies, such as suicidal tendencies, drug abuse and criminal activity. The positive aspect, however, which could act as a counterbalance to that pessimistic perception of the world, is offered by the social and political action we will discuss later. Nevertheless, we should stress that Senior High School students are quite well-informed about the world reality, which is, to a certain extent, also the case with students in the last class of Junior High School (and we refer only to classes where students are taught sociopolitical education subjects), primarily as a result of the information they receive through the Internet and television. Thus, any effort made on the part of teachers to conceal the dark nature of the existing sociopolitical reality can be anything but effective. Therefore, the teaching approach we are introducing here does not present to students something they are unfamiliar with or ignorant about.

What we have mentioned so far, though, relates to Man as a thinking individual, but not necessarily as an active individual, let alone, active citizen; because these facts relate only to a person's way of thinking. Of course, every form of behaviour and "action" presupposes a specific way of perceiving and interpreting the world - in other words, a specific way of thinking. What remains to be seen, however, is how we can find ways that will make people, particularly secondary school students who are tomorrow's adults, develop such a behaviour -which would actually be permanent or almost permanent- and daily attitude to life that will make them intervene in the sociopolitical life and undertake such initiatives and actions-acts that will lead to a considerable improvement of our world. Therefore, finally, the issue is how we can increase the percentage of active citizens, and mainly those who are effective in their interventions and actions; on condition, of course, that their actions express democratic and socially accepted values and also social and political ethics that serve the prosperity of all mankind. (About the content we attribute to this ethics, see Bauman (1994: 33), who has been inspired by the positions of Levinas.) Hence, in essence, we refer to a kind of ethics that responds to the general public interest (or at least, the interest of an entire country) and, under no circumstances, to the "interest" of certain individual social, national or political groups. (In other words, we do not refer to a partial and dividing group (i.e. pertaining only to a certain group) interest). And we do not consider an active citizen to be the citizen who is simply informed about politics or whoever is interested in public affairs or expresses his opinion about them publicly, participating in various (Internet or other) fora. Nor do we consider a citizen to be active when he participates in decisionmaking bodies related to political issues or the process of exercising governance, but whoever undertakes initiatives and participates in collective actions pertaining to issues of public interest - be it in the form of utility projects (such as cleaning a coast) or public protests (such as demonstration). Therefore, almost every act of volunteerism and civil society is considered to be political -in the broader sense of the term. (About civil society, see, indicatively, in Bikos, 2009: 268-269 and about the former content of the term, Vasiliou \& Stamatakis, 1992: 213.)

How can we switch, however, from critical social thinking to educating citizens that would pursue a particular kind of action through which they will intervene in our sociopolitical world to change it? Through critical political thinking. And it is clear that those serving education cannot be satisfied by an action that is not founded upon some kind of thinking or a set of perceptions, as they do not want it to be purposeless and silent, but politically meaningful and conscious.

But let us first see what we mean by the term political thinking. This term, first, denotes the potential of the individual to realise the concept of public interest and also ways in which it can be served on a satisfactory level, as regards every specific issue that concerns society or a social group. Second, the potential of the individual to realise the basic components of the operation of the State and political system. And, third, to realise the tacit relationships of the political system with the social and economic systems. 
Similarly, when using the term, critical political thinking, we mean the way of thinking that allows us, first, to realise the main non-latent causes of political phenomena. Second, to assess the political reality. Third, to assess the ways the public interest is served, as these are proposed publicly regarding the most crucial of the issues that concern society, so that we can ascertain which of these ways are the most effective: that is, which political choices can satisfy the public interest at the least possible social, political and economic cost. And, fourth, to be able to conclude to reasoning that can identify the causes of most political phenomena that we ascertain in our everyday lives, based on logic and the awareness of how the political system works.

But why did we think that in order for the school to be able to turn students to interventional active citizens, as future adults, it should help them cultivate a political critical thinking and not simply a general social critical thinking? Because the field, which is by definition involved in intervening with the social and economic reality aiming to serve the public interest, is politics. Thus, anything that relates to politics or anything that is political is ultimately always connected to an often organised intervention or a proposition for intervention in our world, with the intention of turning it into a better place. On the contrary, cultivating a critical social thinking relates more to nurturing an individual as a thinking, mature, intellectually and socially, subject, rather that shaping the individual as an active subject.

So which special features should characterise the way of thinking that the school will promote to students so that there can be a significant probability for them to act as active citizens who will attempt to change the world? First of all, it should have such a close and intrinsic relationship with behaviour and action that it can itself lead to taking up a value-rational action that would change the world, on the basis of Weber's terminology (1978: 24-25). Thus, it should, first and foremost, promote the idea that the action that intervenes in sociopolitical reality is not assessed simply as a positive or creative form of behaviour (even if it is considered to express the Homo Faber, as defined and analysed by Arendt [1969: 208, 295-296 and elsewhere]), but as an exceptionally important and also necessary form of acting and being in the world, especially today when the world issues are numerous and serious. We refer, in other words, to a perception on the basis of which, in order to consider every thought that relates to society and the State as complete/full it should lead the person who invents it to taking up some action. Besides, this is the only way it can gain the greatest possible value and social importance. Therefore, it is appropriate for the school to cultivate the idea that the thoughts, which express what we just have defined as a politically critical way of thinking, ought, in order to be considered complete as far as their social character/texture is concerned, to end up/turn into sociopolitical action or cause change in the daily behaviour of those who invent them. In other words, they should not remain contemplative, "theoretical" and reserved to themselves; because politics itself which they are involved with, is a field of action, since, in essence, it is an organised, collective and individual provision to ensure social prosperity and serve the public interest and the interests of various social groups, through certain actions, activities, undertaking initiatives and interventions in the current social reality. So, if students are taught that both politics and the State are nothing but a field and a system of interweaving/interrelated acts and actions that aim at tackling social issues and ensuring social prosperity and smooth operation of society and collective life, they will realise much more easily why each political thought should lead to political action and each critical political thought should lead to an intervention in the existing sociopolitical reality.

What we have mentioned above, however, exactly because it is connected to action as a value, it relates to the value orientation towards action, which should characterise the way of thinking that the school ought to cultivate. In order to increase the probability that students act in a way that would reform the world when they become adults, the conditions that we mentioned above are not enough; because it is not enough for this action to be dictated by the students' logic and value system. Students need to be urged also by an unabated/permanent desire to undertake such action. Besides, the will, as a component of the individual based in the intermediate area, between the emotional and intellectual aspect of one's personality, has always been a powerful drive of behaviour, since it is not only related to the intellect but also to the psyche. In other words, in order for the school to fulfill the mission assigned to it, it needs, amongst others, to guide students towards developing attitudes, dispositions and tendencies that would make them want to change the world.

Apart from the above, it is imperative that we refer once again to the subject of teaching methodology, as it defines to a great extent the learning outcome, since it itself teaches skills, abilities, attitudes and 
also, to a certain degree, judgments. E.g. the teaching method that is founded on student's selfmotivation (Koptsis, 2009: 18-19; Matsaggouras, 2000: 283-284; Petsimeri, 2005:46), contributes to developing a spirit of autonomy. (About this autonomy, see, indicatively, in Papakonstandinou, 2000: 119-120, 122-132.) As a result, it teaches him/her something that almost no learning content itself can achieve.

We note, therefore, in the first place, the founding and central role of educators in the school's effort to contribute to shaping active citizens, since if the teacher wishes, he usually can employ his speech, which he freely develops in class, to inject the attitudes and perceptions that we previously introduced into the students. However, we should stress that even if students are taught such perceptions in an explicit verbal manner, it is very difficult to convince them about the strength and truth of this position if the school Curriculum is generally solely knowledge-centered and intellect-centered and only slightly or not at all action-centered; if, in other words, certain (group or individual) activities are not used extensively -inside or outside the school class- as teaching tools. A Curriculum oriented towards action and activities would train students in the process of taking action and initiatives also through hands-on experience, making them even more effective as regards all kinds of action they will need to undertake in the future as adults. (In Karakatsani (2008:152) we read that in recent years concern has been raised regarding the association of the term "active citizen with effective citizen".) But the most important is that such a curriculum would also have certain chances to make some students adopt, even unconsciously, action as a way of living. Unfortunately, though, there are countries, such as Greece, where the secondary school continues to be book-centered and conceptcentered and almost no act-centred/action-centered.

What we have just referred to, though, brings another serious issue to the forefront: the capability of the school to be effective in the field we are discussing. Because in order for citizens to be able to change the world, not only should they wish to do so, but also have the potential and skills necessary to achieve it. Can a school, such as the Greek school, though, provide the necessary assets to the youth so that they can become emancipated citizens, capable to act sociopolitically in an effective manner? Does it really teach them ways to organise collective projects, actions or initiatives and participate effectively in simple conversations, structured dialogues or debates? The secondary school certainly fails to do it sufficiently. As Karakatsani mentions (2008:154), Battistoni -with whom we totally agree- believes that the school should help students develop a series of political skills "such as solving problems of public nature and concern, political judgment, political imagination, [...] collective action". We have also referred both to political judgment, elaborating on the term critical political thinking, and action, talking about action in general, but also political action in particular. We did not, however, put an emphasis on its collective character. Finally, we believe that the term political imagination is related to Mill's term sociological imagination (1985) and can be associated with the perception that we previously suggested, as the one which should be inspired to students about alternative models to organise our sociopolitical world; it can additionally be associated, however, with political thinking and political perception, and also critical political thinking, which we have already analysed.

Before closing our text, we should stress that, in general, the teaching methods usually applied in secondary schools, such as Greek schools, promote, to an excessive extent, especially in sociopolitical education subjects, a knowledge-centrism, not a human-centrism. At the same time, the teaching practices adopted in these subjects do not seem to express the contemporary pedagogical ideas and principles to a satisfactory degree. (Note that even some of the books taught as part of these subjects do not express the new pedagogical and teaching methods.) But neither in the field of setting teaching objectives, as these are described in the relevant legislation of the Ministry of Education, is the school reality fully aligned with the previously mentioned perceptions and principles, but only partly. We should note, though, that one of the factors that does not allow the implementation of these teaching objectives is the limited number of teaching hours specified in the Curricula for teaching each of the teaching modules, while even the teaching methodology proposed in them cannot often be applied as a result of that limited number of hours.

As a result, the syllabus of sociopolitical education and the associated Curricula which provide the basis for its selection should, first, adapt more and truly - i.e. not only on the level of the provisions set out in the different paragraphs of the Curricula that describe the teaching objectives and proposed teaching methodology - to the current sociopolitical needs and the relevant requests of the times. 
Second, they should thoroughly present the existing social reality exactly as it is, presenting its contradictions at the same time. And, third, they should have a clearly value- and human-centered even if not clearly non-individual-centered- orientation. Because the syllabus in question, being intellect-centered, has a reality-centered and institution-centered content, since it is mainly related to information about institutions and their operation and does not present, but only to the minimum, the active role of citizens and the civil society, which may also have the potential of bringing change to the sociopolitical universe. However, it is well-known that one of the key roles and one of the most important obligations of the school is the pedagogic guidance-pedagogic orientation. (Besides, even the word "ped-agogy" in Greek means nothing but the guidance of children.) Thus, in our opinion, today's school much more informs, and offers some knowledge, much less trains, slightly educates, but, sadly, not at all cultivates nor does it lead/guide students towards a path that would make them improve society as a whole, or their life through the improvement they themselves will bring to the social reality they experience and will experience as adults.

\section{Conclusions - Proposals}

Therefore the solution that we propose is to partly reform the curricula and mainly the daily teaching practice (since it has been proved that the latter does not always follow the provisions of regulatory texts, i.e. the Syllabi and circulars issued by the Ministry of Education), so that schools can guide students to ways of thinking and acting capable of changing the world, by improving it. Besides, as Freire has stated, "It is not enough for students to read the word. They need to learn how to read the world". And as Marx stated, "Philosophers have simply interpreted the world. The point is to change it."

\section{REFERENCES}

[1] Arendt, H. (1969). The Human Condition. Chicago and London: The University of Chicago.

[2] Bauman, Z. (1994). Alone Again: Ethics after Certainty. London: Demos.

[3] Mills, W. C. (1959). The Sociological Imagination. New York: Oxford University Press.

[4] Weber, M. (1978). Economy and Society (edited by G. Roth and Cl. Wittich). Berkeley-L.A.-London: University of California Press.

[5] Weber, M. (2017). Methodology of Social Sciences (translated and edited by Edward A. Shils and Henry A. Finch). London and New York: Routledge.

[6] Vasiliou, T.A., \& Stamatakis N. (1992). Lexiko Epistimon tou anthropou (Dictionary of Humanities). Athens: Gutenberg.

[7] Damanaki, M. Koulaidis, V., Kokkos, A., Lamnias, A., \& Dimopoulos, K. (January 2006). Anikto stin kinonia sholio ("A school open to society.") Retrieved on 27/03/2016 from https://eparemvasiax.files.wordpress.com /2009/10/anoikto-sxoleio-pasok-mardamanaki.pdf

[8] Danassis-Afentakis, A. K. (1993). I exelixi tis pedagogikis kai didaktikis skepsis (The evolution of pedagogic and teaching thinking $\left(17^{\text {th }}-20^{\text {th }}\right.$ centuries $)$. Athens: Grigoris Publications

[9] Karakatsani, D. (2008). O rolos tou ekpedeftikou sto plesio tis Kinonikis kai Politikis Ekpedefsis. Epagelmatismos, aftoanaptixi kai didaktikes stratigikes (The role of the teacher within the framework of Social and Political Education. Professionalism, self-development and teaching strategies). In: S. Balias (ed.) Energos politis kai ekpedefsi (Active citizen and education) (p. 151-173). Athens: Papazisis Publications.

[10] Koptsis, A. (2009). Vasikes arhes tis sihronis Didaktikis kai efarmogi tous sti methodologia Project (Basic principles of modern Teaching and their application in the Project methodology) Epitheorisi ekpedeftikon thematon (Review of Teaching Issues), Vol. 15 (p. 16-28). Retrieved on 27/03/2016 from http://www.pischools.gr/download/publications/epitheorisi/teyxos15/016-028.pdf

[11] Korres, K. E. (2007). Mia didaktiki prosegisi ton mathimaton Thetikon Epistimon me ti voithia neon technologion (A teaching approach to Exact Science subjects using new technology). An unpublished thesis, University of Piraeus, Dept. of Statistics and Insurance Science. Retrieved on 27/03/2016 from http://dione .lib.unipi.gr/xmlui/bitstream/handle/unipi/1650/korres.pdf?sequence=3\&isAllowed=y

[12] Kiriakides, P. (2006). Kritiki skepsi (Critical thinking). Minutes of the $3^{\text {rd }}$ Panhellenic Conference of the Institute of Applied Pedagogy and Education, $13^{\text {th }}$ and $14^{\text {th }}$ May, (p. 99-110). Athens. Retrieved on 24/04/2016 from http://www.elliepek.gr/documents/3o_synedrio_eisigiseis/kyriakides.pdf

[13] Matsagouras, I. G. (2000). Theoria kai praxi tis Didaskalias (Theory and practice of Teaching) Vol. B: Stratigikes didaskalias: I Kritiki Skepsi sti Didaktiki Praxi. (Teaching strategies: Critical thinking in the Teaching Act). Athens: Gutenberg. 
[14] Bikos, G. (2009). Politiki kai Dikeo: B Likiou Genikis Pedias (Politics and Law: $2^{\text {nd }}$ Class of Senior High School - General Education Subjects). Athens: Metaixmio.

[15] Pedagogic Institute (2011). Basic Training Material: I Axiopiisi ton technon stin ekpedefsi (Employing the Arts in education). Volume C. Retrieved on 13/01/2014 from http://www.epimorfosi.edu.gr/

[16] Papakonstandinou, P. (2000). Pedagogiki shesi kai aftonomia (Pedagogic relationship and autonomy). In: A. Gotovos, G. Mavrogiorgos \& P. Papakonstandinou. Kritiki pedagogiki kai ekpedeftiki praxi (Critical pedagogy and teaching act) (p. 119-133). Athens: Gutenberg.

[17] Petsimeri, E. (2005). Didaktiki Methodologia: Didaktiki ton Archeon Ellinikon (Teaching Methodology: Teaching Ancient Greek). Athens: Grigoris Publications.

\section{AUTHOR'S BIOGRAPHY}

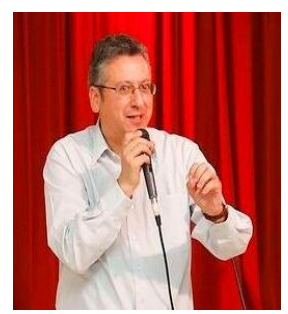

Georgios Bikos was born in Athens on 30/10/1967. He holds a Degree in Political Science, Sociology, Pedagogical Studies, a Master's Degree in Public Policy and a Doctorate in the field of Political Science and its Teaching. He is currently principal of the $7^{\text {th }}$ Senior High School of Kallithea, Athens. He also teaches at the Hellenic Open University, the University of Western Attica (History and Sociology of Reading), the School of Pedagogical and Technological Education (Methodology of Teaching) and the University of Athens, Pedagogical Dept. of Primary Education (Political Rhetoric) for a Postgraduate Programme. He is Director-Scientific advisor at GRIGORIS publications (Athens). His previous and current interests include fields such as History of Education, Theory and History of Reading and Teaching Methodology.

Citation: Georgios D. Bikos. " On Teaching Political Education Subjects in Secondary Education" International Journal of Humanities Social Sciences and Education (IJHSSE), vol 5, no. 7, 2018, pp. 150-156. doi: http://dx.doi.org/10. $20431 / 2349-0381.0507017$.

Copyright: () 2018 Authors. This is an open-access article distributed under the terms of the Creative Commons Attribution License, which permits unrestricted use, distribution, and reproduction in any medium, provided the original author and source are credited. 